\title{
The Effect of Conjunction Flexibility on the Local Stability of Steel Thin-walled Slab Beams
}

\author{
Vladimir Rybakov ${ }^{1, a}$, Natalia Molchanova ${ }^{1}$, Vladimir Laptev ${ }^{1}$, Anna Suslova ${ }^{1}$ and Aleksandr Sivokhin ${ }^{1}$ \\ ${ }^{1}$ St. Petersburg State Polytechnical University, 29, Polytecknycheskaya st., St. Petersburg, 195251, Russia
}

\begin{abstract}
Influence compliance of node connections are not taken into account fully in the existing calculation methods. Basically, this is because of insufficient three-dimensional interference knowledge of elements of thin-walled steel frames. In practice, the structural analysis of the LSTC is usually made with the help of design diagrams with articulated or rigid joints connection elements, therefore, real behavior of structure is not taken into account, as the compliance units may lead to substantial redistribution efforts. Researches in clarifying the design diagrams allow to calculate the steel thin-walled structures with more accuracy and to improve the economic efficiency of design solutions. Thus, the purpose of the study is to determine the qualitative and quantitative characteristics on the basis of experimental and numerical studies that affect the loss of local stability in joints, taking into account the compliance of node connections.
\end{abstract}

\section{Introduction}

Nowadays there is a significant increase of thin-walled molded sections from galvanized steel in the construction industry, which shows that there is an evolution of new technologies in Russia. These new technologies provide many things such as research, development, engineering, production and building of light steel thin-walled constructions (LSTC). Construction technology based on the use of thin-walled molded sections can be used independently or in cooperation with other types of building structures. This technology allows to build high-quality and cost-effective buildings in a short of time, which allows production in remote areas. Moreover this is particularly relevant in emergency response and recovery. LSTC-technology allows you to build additional structures and mansard roofs without foundations strengthening due to the small weight of the structures, as well as residential, public and industrial buildings $[1,2]$. The most common theory of thin-walled calculation was developed by V.S. Vlasov [3]. Theoretical developments listed in his works [3, 4], confirmed by numerous experimental studies that uses this theory to build an engineering method for calculating thin-walled open section. Equations of sustainability have been clarified by Broude B.M. [5] and Vorobiev L.N. [6]. Calculation of thinwalled bars of the deformed scheme were studied by Vyazmenskiy S.P. [7], Beilin E.A. [8], Meshcheryakov V.B. [9]. Influence of initial imperfections on the behavior of thin-walled structure is investigated by Broude B.M. [5]. Sustainability issues of thin-walled bars were considered by Repmanom Y.V. [10]. Stability of plane bending of thin-walled, studied by Reut V.I. [11], Moulin S.M. [12], Obrazcov I.F. [13]. Development of calculation methods are devoted to Bychkov D.V. [14-

\footnotetext{
${ }^{\text {a }}$ Corresponding author : author@e-mail.org
} 
16], Gorbunov B.N. [17], Strelbitskaiya A.I. [17], Beliy G.I. [18, 19], Tusnin A.R. [20], Lalin V.V. $[21,22]$, Rybakov V.A. [21-24]and other scholars. Application of thermoprofiles is also studied widely [25-28]. There are a lot of impressive studies related to thin-walled bars made by hand of Russian [29-34] and foreign authors [35-42]. A large number of studies are also related to the study of node connections of thin-walled structures. Research in bolted connections and in the development of methods for their calculations are devoted to Streleckiy N.N. [43, 44], Babushkin V.M. [44, 45], Velikhov V.P. [45]. Influence on zinc covering on the work of the node connections is considered by Sotskov N.I. and Yakubov G.P. [46]. Issues of the work of node connections using rivets and screws are devoted to Orlov I.V. [47, 48], Ayrumyan E.L. [49] Ganichev S.V. [50]. Classification of node connections is shown in the article [51]. The significant gap in node connections of thin-walled structures requires research into the deformation of node connections to the thread-cutting screws [52, 53]. Due to the deformability in nodes of construction there are additional displacement and a redistribution of internal forces in the structural elements caused by deformations in the local connection area.

\section{Materials and Methods}

Behavior of used test pieces was equal to work of a thin walled steel slab beams. The experimental model consists of a thin walled steel beam (Type PS-150, length $800 \mathrm{~mm}$ ), 2 profiles (type PN-154, each length $400 \mathrm{~mm}$ ) and timber inserts. Beams of type PS-150 simulate a work of the floor slab. Profiles of type PN-154 act as a guides. Timber bars were used as an inserts to provide more stiffness for the construction and imitate angles in the beam connections. Some of the test pieces were carried out using angles for strengthening a wall of the profile. Angles fixation was situated on the distance of $200 \mathrm{~mm}$ from beam verges (type PS-150). All elements are connected by thread forming screw.

11 test pieces of 4 types were examined. The difference between test pieces is in profile thickness and angle stiffener (its existence or absence).

-Test pieces with the beam of a type PS-150-1.5 without angle stiffeners

- Test pieces with the beam of a type PS-150-2.0 without angle stiffeners

- Test pieces with the beam of a type PS-150-1.5 with angle stiffeners

- Test pieces with the beam of a type PS-150-2.0 with angle stiffeners

The research model is a single-span beam with a hinge support. The following hypothesis was taken for an experiment simplification: distributed load is substituted by two single forces, applied at a distance $200 \mathrm{~mm}$ from the supports. As a result, we have a beam situated in the conditions of pure bending, because the bending moment between two points is constant. Load increase is being carried out by steps of $100 \mathrm{KGS}$. Load scheme is shown on the Figure 1.

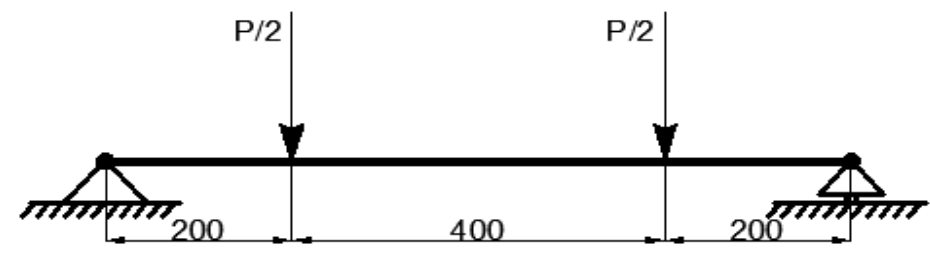

Figure 1. Loading scheme

The aim of the experiment is to determine the critical load. Appearance of a load curve plateau (its decrease or permanence in the time of the deflection increase) is a characteristic feature of the bearing depletion and stability loss. Outward signs of the stability loss are:

The experimental unit and test pieces view is shown on the Figure 2. 


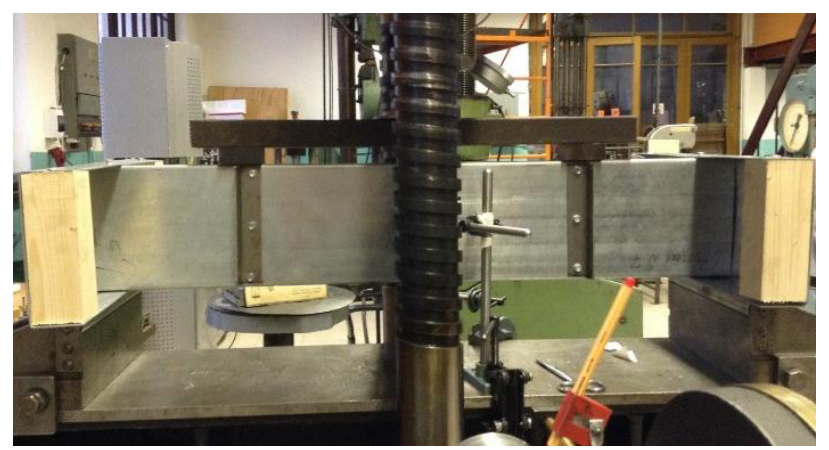

Figure 2. Experiment set-up

Obtained values of the critical forces are shown in the table 1.

Table 1. Critical loadings

\begin{tabular}{|c|c|c|}
\hline Test piece's type & $\mathrm{F}_{\text {кр }}, \mathrm{daN}$ & $\overline{\mathrm{F}_{x \rightarrow 0}}, \mathrm{daN}$ \\
\hline \multirow{3}{*}{$\begin{array}{l}\text { Test pieces with the beam type PS-150-1,5 } \\
\text { without angle stiffeners }\end{array}$} & 1800 & \multirow{3}{*}{1776} \\
\hline & 1700 & \\
\hline & 1830 & \\
\hline \multirow{3}{*}{$\begin{array}{l}\text { Test pieces with the beam type PS-150-2,0 } \\
\text { without angle stiffeners }\end{array}$} & 2500 & \multirow{3}{*}{2360} \\
\hline & 2100 & \\
\hline & 2480 & \\
\hline \multirow{3}{*}{$\begin{array}{l}\text { Test pieces with the beam type PS-150-1,5 with } \\
\text { angle stiffeners }\end{array}$} & 1830 & \multirow{3}{*}{1920} \\
\hline & 2150 & \\
\hline & 1780 & \\
\hline \multirow{2}{*}{$\begin{array}{l}\text { Test pieces with the beam type PS-150-2,0 with } \\
\text { angle stiffeners }\end{array}$} & 2400 & \multirow{2}{*}{2500} \\
\hline & 2600 & \\
\hline
\end{tabular}

Critical force analysis shows that the metal thickness increase of the profile leads to bearing capacity increase (approximately 25\%). Deformation type is the same in the time of the steel thickness increase. The angle stiffener installation influences a geometry change and stability loss type of the test piece, but it increases bearing capacity quite unessentially (not much that on $10 \%$ ).

Let's consider deformations which appear in the each of the different test pieces.

Test pieces with the beam type PS-150-1, 5 without angle stiffeners (Figures 3, 4): right after the load is applied, the upper board profile has a deformation and deflection, then, there is deformation under the bars, which transmit loading and profile crumple occurs. Otherwise, the lower board incurves up into the profile. At the same time, the wall under the bars is being buckled. Local stability loss starts to develop. Maximum loading is situated under the bars, transmitting the loading. Then, there are two options of the deformation development: in the direction of a central part of bended profile or in the direction of obstacles.

As deformation develops from the walls under the bars to the central part of a beam, all central parts of the beam are being buckled. In case of the deformation development towards the obstacles, in the profile connections there is a crumple of a lower wall part. Destruction is possible because of a pulling out of the thread forming screw (Figure 4). Deformation of obstacles is obtained and it is expressed by the board deformation of the profile guides.

Asymmetric deformation development is possible as well. On the one hand deformations are developing in the direction of the beam's central cross-section; on the other hand deformations are developing in the direction of the joint. 


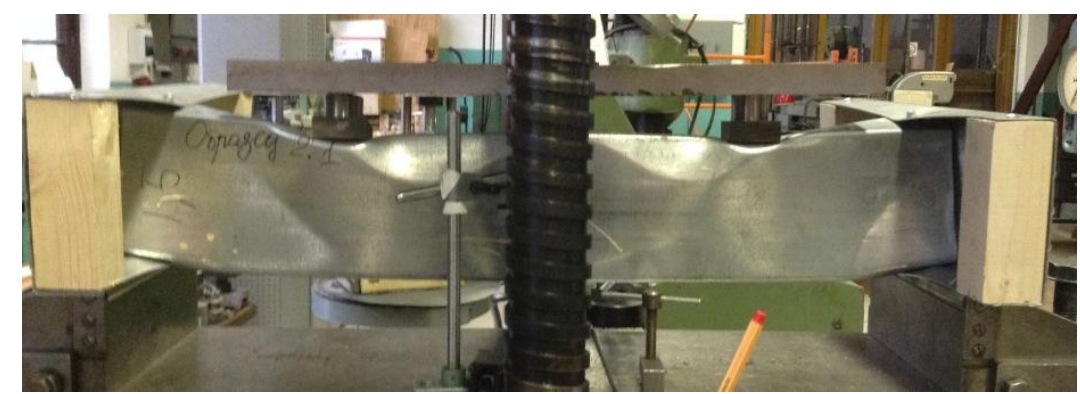

Figure 3. View of the deformed test piece

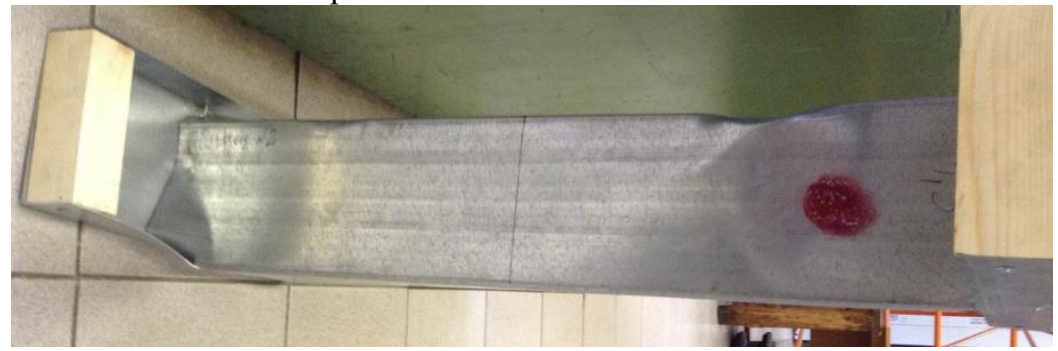

Figure 4. View of the deformated test piece

Test pieces with the beam type PS-150-2,0 without angle stiffeners: deformations are similar to previous test pieces deformations but they are less expressed. Essential obstacle obliquity is observed as well.

Test pieces with the beam type PS-150-1, 5 with angle stiffeners: (Figures 5, 6, 7): angle stiffeners essentially change the deformations behavior.

After applying load, buckling occurs under the bars, which transmit the load. By the way, deformations caused by profiles buckling essentially decrease in the beam's central part. There is unessential bulging of the upper part of the wall. Lower part of the wall is almost not deformed.

Deformations in the direction of the obstacles have a similar behavior to the test pieces without stiffer angles: profile's wall stays straight in the area which is close to angle stiffeners. But in the area which is far from angle stiffeners there is a fast deformation development: buckling of the lower wall part, deformation of the guide profiles, and sometimes the destruction because of a pulling out of the thread forming screws.

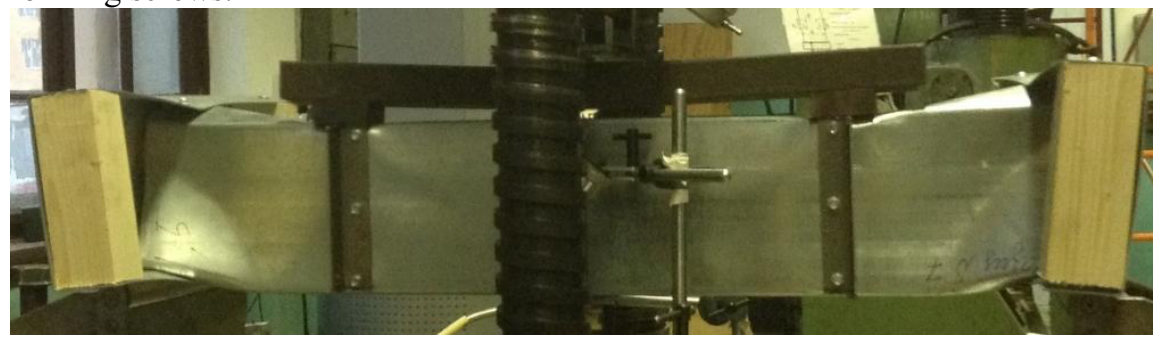

Figure 5 - View of the deformated test piece 


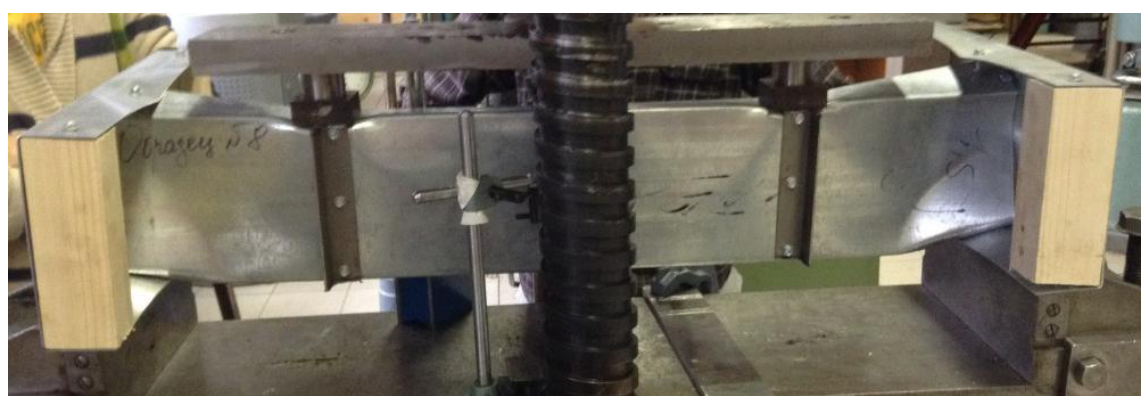

Figure 6. View of the deformed test piece

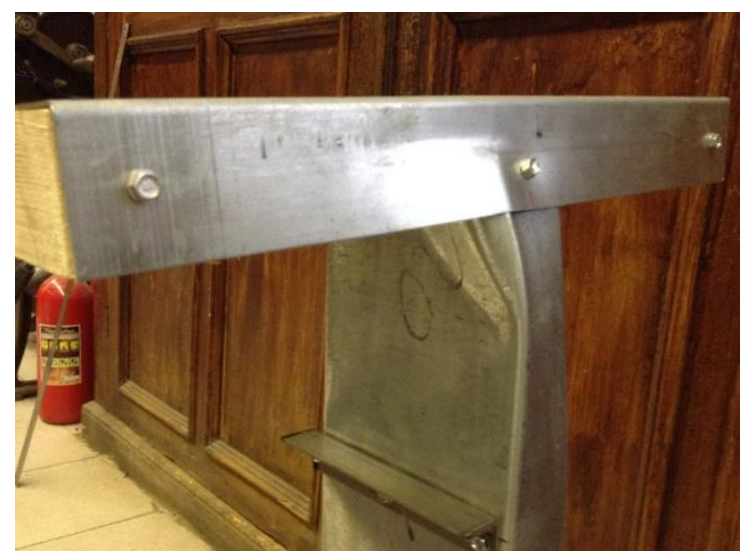

Figure 7. Deformation of the profile's guide of the board

Test pieces with the beam type PS-150-2 with angle stiffeners: deformations are similar to those described previously, but less expressed. Essential obliquity of the obstacles is obtained.

\section{Results and discussion}

Intensive numerical method development of calculations allows simulation of the interaction processes of the steel thin walled constructions and make three-dimensional calculations with the required accuracy. Finite elements method is the most widely spread method [54].

Calculation was carried out in the ANSYS software. The geometrical model was created using Design Modeler, which use modern methods of the modeling plane and 3D geometry. Geometrical models are shown on the Figures 8 and 9.

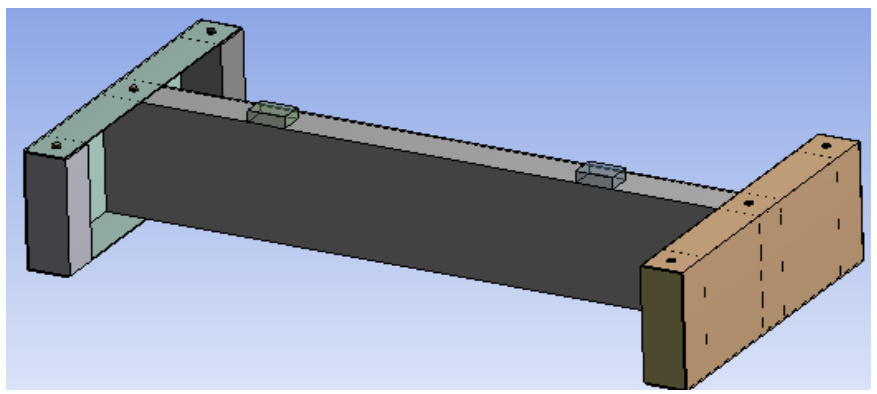

Figure 8. Geometrical model without angle stiffeners 


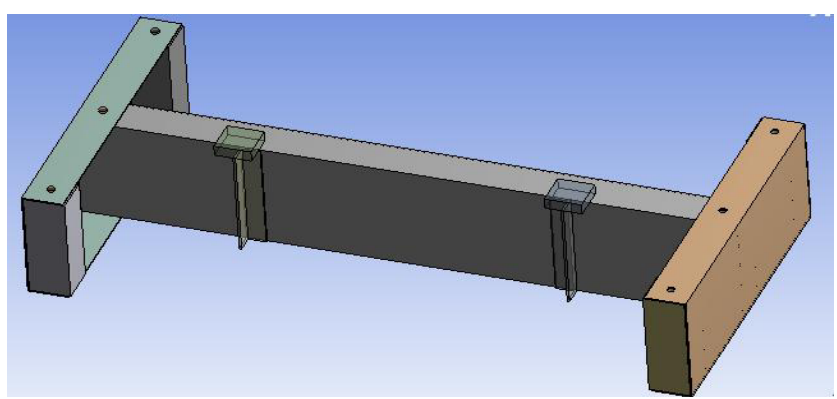

Figure 9. Geometrical model with angle stiffeners

Deformation behavior in the geometrical models is detailed in the table 2. Deformations of the test pieces with the different profile's thicknesses are equal.

Table 2. Appearance of the deformed test pieces

\begin{tabular}{|l|l|l|}
\hline №. & \multicolumn{1}{|c|}{ Type } \\
\hline 1 & $\begin{array}{l}\text { Test pieces with the beam type } \\
\text { PS-150-1,5 without angle } \\
\text { stiffeners; } \\
\text { Test pieces with the beam type } \\
\text { PS-150-2,0 without angle } \\
\text { stiffeners }\end{array}$ \\
\hline 2 & $\begin{array}{l}\text { Test pieces with the beam type } \\
\text { PS-150-1,5 with angle stiffeners; } \\
\text { Test pieces with the beam type } \\
\text { PS-150-2,0 with angle stiffeners }\end{array}$ \\
\hline
\end{tabular}

Analysis of calculations showed that collected calculated deflections and deformations are the same as measured ones.

Deflections in the central sections of test pieces are similar to measured ones. Values of the same magnitude are received. Differences in values of deflections are the idealized model. Moreover it doesn't reflect initials imperfections of test pieces. Thus there is a differences in connections: in the calculated model they are ideal but in the measured model, some test pieces a displacement of supports with an increase of stress was obtained. To increase guided profile's roughness special bodies were set. They imitate wooden insertions but imperfections of wooden bars, used in the installation of test pieces (some of wooden bars were destroyed during the experiment), are not considered.

Deformation behavior in calculated models is similar to deformations from the experiment. Deformation of sections appeared in the time of load application - in central section and near the obstacles. The largest deformation of wall appears in the place of load transmission. Deformation behavior of profile's boards and deformation of test profile is similar. Deformation of obstacles' profiles are observed as well. 
Thus, collected calculated forms of test pieces' deformation allow to make a conclusion that the calculated form with high accuracy describes a deformation which appeared in the time of bearing capacity of thin-walled profiles' loss.

Since calculated and measurable materials demonstrate obstacles' deformability, due to guided profile boards' deformation, that obstacles are resilient. Moreover force distribution is not the same for rough or hinge scheme of supports. The scheme of thin-walled beam's supported in the time of node connections' deformability is shown in the Figure 10.

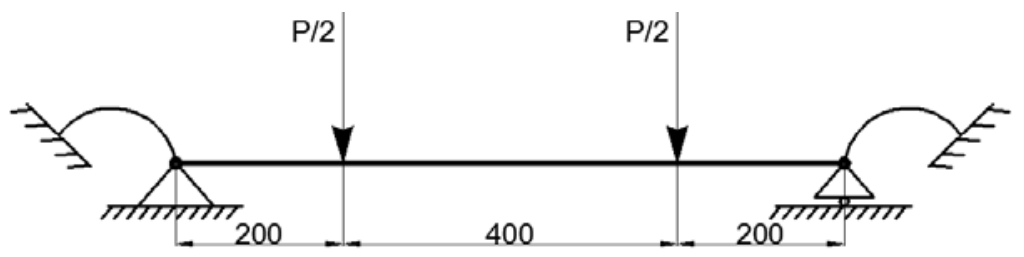

Figure 10. Scheme of thin-walled beam's supporting with obstacle's deformability

Let's express the relation of stresses in the end of steel thin-walled beam's section through the coefficient $\mathrm{k}_{\mathrm{n}}$ considering deformability of node connection:

$$
\frac{\sigma_{f l}}{\sigma_{s t}}=\mathrm{k}_{n}
$$

Where $\sigma_{\mathrm{fl}}$ и $\sigma_{s t}$ - direct stressed in a way of resilient and rough supporting accordingly.

Values of direct stresses in both ways could be made from the result in calculations using finite elements method. The whole construction is calculated to determine direct stresses in a way of resilient support. In a way of rough obstacles calculation for which the following is provided: besides current fixation rough support of low profile's boards defines; its deformation is about deformability of node connection.

Typical points of thin-walled profile's cross-section are in the Figure 11. For these points values of node connections in sections were determined. Then value of coefficient $\mathrm{k}_{\mathrm{n}}$ is calculated. In the Figure 12 there is a graph of coefficient $\mathrm{k}_{\mathrm{n}}$ for all points of section.

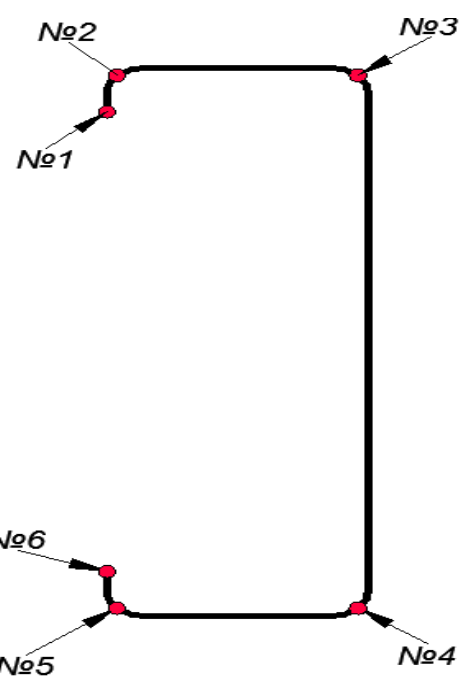

Figure 11. Typical profile's points PS 


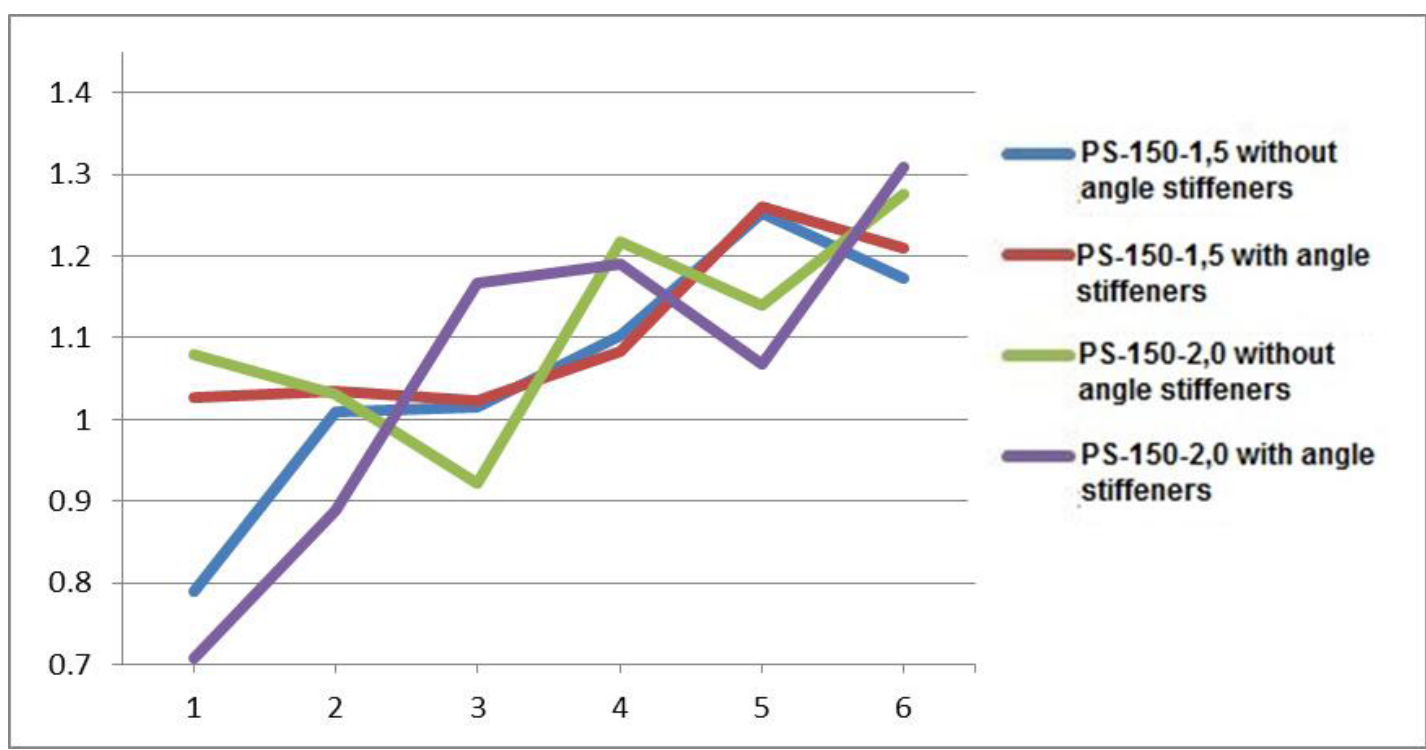

Figure 12. Values of coefficient for typical points of cross-section

According to calculations, the values of direct stresses in the end of thin-walled beam's section is increasing allowing for the deformability of supporting profile.

Total direct stress for thin-walled beams with bend is determined from the formula which takes into account bar's rotation and warping [55]:

Where:

$$
\delta_{\mathrm{sum}}=\delta_{\mathrm{My}}+\delta_{\mathrm{Mz}}+\delta_{\mathrm{W}}
$$

$\delta_{\mathrm{My}}-$ direct stress from bending moment $\mathrm{M}_{\mathrm{y}}$;

$\delta_{\mathrm{Mz}}-$ direct stress from bending moment $\mathrm{M}_{\mathrm{z}}$;

$\delta_{\mathrm{W}}-$ direct stress from warping.

Only bending moments arise in a case of rough supporting of considering thin-walled beams in the end of profile's section. The amount of stress from warping and rotation is not essential. Deformability of obstacle due to guided profile's board deformation determines a big compliance of bending beam's cross-section. In other words stress of rotation and warping has higher role.

Let's say that coefficient $\mathrm{k}_{\mathrm{n}}$ for each considering model is an arithmetical average of profile ambit's coefficients (Table 3).

Table 3. Coefficient $\mathrm{k}_{\mathrm{n}}$ for considering test pieces

\begin{tabular}{|c|c|c|}
\hline Type of profile & $1 / \mathrm{k}_{\mathrm{n}}$ & $\mathrm{k}_{\mathrm{n}}$ \\
\hline PS-150-1,5 without angle stiffeners & 0.852 & 1.172 \\
\hline PS -150-2,0 without angle stiffeners & 0.823 & 1.215 \\
\hline PS -150-1,5 with angle stiffeners & 0.828 & 1.208 \\
\hline PS -150-2,0 with angle stiffeners & 0.838 & 1.192 \\
\hline
\end{tabular}

Relation between direct stresses in a way of rough and resilient supporting is almost the same. This allows to suppose that node connection's deformability doesn't depend on the type of beam and existence or absence of angle stiffener.

Calculations allow us to make a conclusion that deformability's accounting of bearing construction provides to the increase of collected direct stresses of $15-20 \%$. Therefore, when calculating we should use a coefficient which takes into account an effect of node connections' deformability on the state of stress of thin-walled beam. It equals to 1,2. Coefficient of node connections' deformability doesn't depend on the type of bending beam and existence of angle stiffener because a deformability is about a deformation of guided profiles' board. 


\section{Conclusions}

Analysis of test results showed that the girders' sustaining capacity strongly depends on the thickness of steel - increase in profile's thickness of $0.5 \mathrm{~mm}$ gave an increase in the girders' sustaining capacity of about $25 \%$.

The use of strengthening ribs has a significant impact on the local loss of stability and allows to save the section of the central profile's part almost unchanged, but doesn't produce a significant effect when used in floor beams - sustaining capacity increased by only $10 \%$.

It was considered a deformability of node connections expressed by deformations of shelves guide's profiles. According to the calculation, the normal tensioning is in the end sections of thin-walled beams, taking into account that the deformability increases by 1.2 times.

Compliance coefficient of node connection does not depend on the type of beam's bend and the presence or absence of ribs.

\section{References}

1. N.I. Vatin, Ye.N. Zhmarin, V.G. Kurazhova, K.Yu. Konstruirovaniye zdaniy i sooruzheniy. Legkiye stalnyye tonkostennyye konstruktsii: ucheb. rukovodstvo (Saint-Petersburg, 2012)

2. K.V. Petrov, Ye.A. Zolotareva, V.V. Volodin, Vatin N.I., Zhmarin Ye.N. Magazine of Civil Engineering, 2, 59-64 (2010)

3. V.Z. Vlasov, Tonkostennyye uprugiye sterzhni (Moscow, Fizmatgiz, 1959)

4. V.Z. Vlasov, Izbrannyye trudy. Part 3. (Moscow, Nauka, 1964)

5. B.M. Broude, Raschet prostranstvennykh konstruktsiy, 4, 5-35 (1958)

6. L.N. Vorobyev, Novocherkasskiy politekhnicheskiy institut.-Novocherkassk: NPI, 69(83), 3-48 (1958)

7. S.P. Vyazmenskiy Leningr. Inzh.-stroit. in-t.- L.: LISI, 60, 20-29 (1969)

8. Ye.A. Beylin, Stroitelnaya mekhanika i raschet sooruzheniy, 4, 1-3 (1967)

9. V.B. Meshcheryakov, Sb.nauchn.tr., Moscow, Transzheldorizdat, 236, 77-85 (1967)

10. Yu.V. Repman, Trudy laboratorii stroitelnoy mekhaniki, 1, 154-211 (1941)

11. V.I. Reut, Problemy ustoychivosti v stroitelnoy mekhanike: Tr. Vsesoyuz. konf. po problemam ustoychivosti, 1, 466-483 (1965)

12. S.M. Mulin, Issledovaniye ustoychivosti ploskoy formy izgiba (Tomsk, 1950)

13. T.V. Nazmeyeva, Magazine of Civil Engineering, 5(40), 44-51 (2013)

14. Ye.A. Beylin, Stroitelnaya mekhanika i raschet sooruzheniy 4, 1-3 (1967)

15. D.V. Bychkov Raschet balochnykh i ramnykh sterzhnevykh sistem iz tonkostennykh elementov, (Moscow, 1948)

16. D.V. Bychkov, Structural Mechanics of stalky thin-walled structures (Moscow, 1962)

17. B.N. Gorbunov, A.I. Strelbitskaya, Teoriya ram iz tonkostennykh sterzhney (Moscow, 1948)

18. G.I. Belyy, Metallicheskiye konstruktsii i ispytaniya sooruzheniy LISI, 1, 26-30 (1984)

19. G.I. Belyy Sbornik trudov LISI, 11, 18-25 (1974)

20. A.R. Tusnin, Chislennyy raschet konstruktsiy iz tonkostennykh sterzhney otkrytogo profilya (Moscow, MGSU, ASV, 2009)

21. V. V. Lalin, V. A. Rybakov, Magazine of Civil Engineering, 8(26), 69-80 (2011)

22. Lalin V. V., Rybakov V. A., Morozov S. A., Magazine of Civil Engineering, 1(27), 53-73 (2011)

23. V. A. Rybakov Osnovy stroitelnoy mekhaniki legkikh stalnykh tonkostennykh konstruktsiy (SaintPetersburg, SPbGPU, 2011)

24. V. A. Rybakov, O. S. Gamayunova, Construction of Unique Buildings and Structures, 7(13), 79 (2013)

25. N. I. Vatin, Ye. N. Popova, Termoprofil v legkikh stalnykh stroitelnykh konstruktsiyakh (SaintPetersburg, SPbGPU, 2006)

26. A. O. Gordeyeva, N. I. Vatin, Magazine of Civil Engineering, 3, 36-46 (2011)

27. Obraztsov I.F., Sb. nauch. tr. Mosk. aviats. in-t, 26, 85 (1953) 
28. A. V. Orlova, Ye. N. Zhmarin, K. O. Paramonov, Construction of Unique Buildings and Structures. 6(11), 1-13 (2013)

29. M.R. Garifullin, N.I. Vatin, Construction of Unique Buildings and Structures, 6(21), 32-57 (2014)

30. D.N. Smaznov, Politematicheskiy Setevoy Elektronnyy Nauchnyy Zhurnal Kubanskogo Gosudarstvennogo Agrarnogo Universiteta, 67, 101-113 (2011)

31. V.V. Lalin, V.A. Rybakov, A. Sergey, Applied mechanics and materials, 578-579, 858-863 (2014)

32. D. Trubina, D. Abdulaev, E. Pichugin, V. Rybakov, Applied mechanics and materials, 633-643, 982-990 (2014)

33. D. Trubina, D. Abdulaev, E. Pichugin, V. Rybakov, Applied mechanics and materials, 633-643, 1133-1139 (2014)

34. D. Trubina, D. Abdulaev, E. Pichugin, M. Garifullin, Applied mechanics and materials, 633-643, 1052-1057 (2014)

35. K. M. Bajoria, K. K. Sangle, R. S. Talicotti, International Journal of Advanced Structural Engineering, 1(2), 153-181 (2014)

36. J. Becque, M. Lecce, J. Rasmussen, R. Kim, Journal of Constructional Steel Research, 64(11), 1231-1238 (2008)

37. J. H. Bickford An introduction to the design and behavior of bolted joints, 3rd edition (2009)

38. Ju Chen, B. Young, Engineering Structures, 10(29), 1161-1174 (2007)

39. C. N. Louise, A. M. Md Othuman, M. Ramli, Applied Science Research, 3(5), 2847-2859 (2012)

40. A. G. Mamalis, D. E. Manolakos, M.B. Ioannidis, P.K. Kostazos, C. Dimitriou, Thin-Walled Structures, 41(10), 891-900 (2003)

41. J. R. Rasmussen, J. Kim, Thin-Walled Structures, 44(11), 1175-1184 (2006)

42. Silvestre N., Young B., Camotima D, Engineering Structures, 10(30), 2613-2630 (2008)

43. N.N. Streletskiy, V.V. Kalenov A.B. Pavlov, Mezhdunarodnyy kollokvium. Boltovyye i spetsialnyye montazhnyye soyedineniya v stalnykh stroitelnykh konstruktsiyakh, 1, 14-22 (1989).

44. V.M. Babushkin, Mezhdunarodnyy kollokvium. Boltovyye i spetsialnyye montazhnyye soyedineniya v stalnykh stroitelnykh konstruktsiyakh, 1, 105 (1989)

45. V.P.Velikhov, V.M. Babushkin, Provedeniye issledovaniy boltovykh montazhnykh soyedineniy, rabotayushchikh na srez, rastyazheniye $i$ smyatiye, i razrabotka 135 predlozheniy po izmeneniyu $i$ dopolneniyu SNiP P-23-81. Otchet OTIZM-872 (Moscow, 1985)

46. N.I. Sotskov, Montazhnyye i spetsialnyye raboty v stroitelstve, 11, 34-37 (2005)

47. I.V. Orlov, Tekhnologii stroitelstva, 7(41), 5 (2005)

48. I.V. Orlov, Tekhnologii stroitelstva, 6(47), 14 (2008)

49. E.L. Ayrumyan, Montazhnyye i spetsialnyye raboty v stroitelstve, 3, 19-20 (2009)

50. S.V. Ganichev, Tekhnologii stroitelstva, 3(65), 22 (2009)

51. V. G. Kurazhova, T. V. Nazmeyeva, Magazine of Civil Engineering, 3, 47-52 (2011)

52. Yu.S. Kunin, A.I. Kolesov, I.A. Yambayev, D.A. Morozov, Herald MGSU, 11, 74-81 (2012)

53. S.V. Salamakhin, A.S. Sinelnikov, Construction of Unique Buildings and Structures, 4(9), 53-63 (2013)

54. V.A. Bruyaka, V.G. Fokin, Ye.A. Soldusova, H.A. Glazunova, I.Ye. Adeyanov, Samar. gos. tekhn. un-t., 1, 271 ( 2010)

55. Eurocode 3: Design of steel structures Part 1-3. General rules. Supplementary rules for coldformed members and sheeting (2006) 